\title{
Testicular Cancer pM1a TNM Finding v7
}

National Cancer Institute

\section{Source}

National Cancer Institute. Testicular Cancer pM1a TNM Finding v7. NCI Thesaurus. Code C89255.

Testicular cancer with non-regional nodal or pulmonary metastasis. (from AJCC 7th Ed.) 